\title{
Collaborative Procurement within Enterprise Networks: A Literature Review, a Reference Framework and a Case Study
}

\author{
Luca Cagnazzo, Paolo Taticchi, Gianni Bidini, and Mohamed Sameh \\ Department of Industrial Engineering, University of Perugia, \\ Via Duranti 67, Perugia, Italy \\ luca.cagnazzo@unipg.it, \\ paolo.taticchi@unipg.it, \\ gbidamach.ing.unipg.it
}

\begin{abstract}
Collaboration among companies is nowadays a success leverage from those involved, especially for SMEs. The networking advantages are several and among them, reducing costs is a critical one. Costs reduction due to the possibility of Collaborative Procurement (CP) among partners is one of the most important achievements in a network. While the literature available offers good bases for managing single contractor procurement issues, little research addresses the case of $\mathrm{CP}$ within Enterprise Networks (ENs). This paper explore the mentioned issue and proposes a general framework for managing CP in ENs, those with the Virtual Development Office (VDO) structure. The findings from the application of the framework proposed in an Italian network are highlighted so as to provide preliminary results and drive future research.
\end{abstract}

Keywords: Enterprise Network, Collaborative Procurement, SME, Virtual Development Office, Case Study.

\section{Introduction}

Several forms of structured collaborative organizations are growing up in the last decade, with different degree of formal relationships. Industrial clusters, districts, Virtual Organizations (VOs), Virtual Enterprises (VEs), Virtual Breeding Environment (VBE) [1], Collaborative Networks (CNs), are samples of collaborative enterprise networks. The most important advantages of these typologies of stable collaborations can be reassumed in developing new products/services, sharing new knowledge and risks, being part of critical mass and reducing costs [2], [3] and [4]. For the last purpose, one of the most important action within a collaborative environment is the Collaborative Procurement (CP) among partners, since through global purchasing with common suppliers it is notably possible to reduce costs and risks, as well as increase the contractual influence since the achievement of a sufficient critical mass. The article is organized as follows. In Section 2 we discuss the CP concepts, followed by a literature review on this topic in Section 3 that highlights the evolutions of the CP concept during the last decades. In section 4 we illustrate the particular network model, the Virtual Development Model 
(VDO), in which the new CP framework has been adopted: the case study is indeed discussed in Section 5, considering the GPT (Gruppo Poligrafico Tiberino) success case as the first Italian network adopting the VDO structure. Concluding remarks and further developments are presented in Section 6.

\section{Collaborative Procurement Concept}

CP has so far been loosely defined in the existing literature. It is referred to as horizontal cooperative purchasing, group purchasing, collaborative purchasing, collective purchasing, joint purchasing, consortium purchasing, shared purchasing, bundled purchasing, etc. And this list goes on to about a hundred terms [5]. As a concept, the $\mathrm{CP}$ covers a very wide spectrum of possible definition, related to the systems in which it is applied, the involved actors, the relationship among subjects, etc. However a basilar definition is: $\mathrm{CP}$ is an effective way for more than one client, contractor, consultant or supplier to join together to procure works, services, materials or goods, share expertise, promote efficiency and deliver value for particular advantages in the delivery of a project, series of projects or service objectives [6]. In the literature, several general types of cooperation for $\mathrm{CP}$ are distinguished. A main distinction is between horizontal CP, i.e. buyer-buyer or seller-seller cooperation, and vertical CP, i.e. buyer-seller cooperation [7]. When referring to horizontal $\mathrm{CP}$, concepts apply such as shared service centers, horizontal alliances, and horizontal cooperative purchasing. When referring to vertical cooperation, concepts apply such as co-makership, vertical alliances, and public-private partnerships. In this paper, we focus on horizontal CP, in terms of buyer-buyer actors (companies belonging to the same network). The main advantages of CP are more or less similar to advantages of coordinated or centralized purchasing in a single organization. The advantages follow from factors such as economies of scale [8], a reduced number of transactions between suppliers and buyers [9], improved relationships with suppliers and other organizations in the purchasing group, and stronger negotiation positions. Reported disadvantages of CP follow from factors such as an increased complexity of the purchasing process and loss of flexibility and control. However, the advantages of cooperative purchasing outweigh the disadvantages for many situations in the public and private sector [5].

\section{Literature Review}

A brief history of the CP concept can be developed starting from the early 1970s, when purchasing was viewed as having a passive role in the business organization [10]. This view was supported at that time by many strategists who stated that purchasing could be described as an administrative rather than a strategic function. There were, however, some people, for example, [11] and [12], who stressed in their articles the need to include purchasing in corporate planning. According to [13] the 1980s were a period of shifting attitudes towards the role of purchasing in corporate strategy. As a function, purchasing was claimed to be capable of being a source of competitive advantage for 
the business. [14] proposed that purchasing can contribute to corporate strategy in four different ways: monitor supply market, interpret the meaning of these trends for the firm, identify the materials and services required to support company and strategic business unit strategies and develop supply options. [15] discussed the contribution of purchasing in terms of strategic resources and the need to manage key materials in relation to product/market objectives of the particular businesses. In the end of 1980s [16] captured the spirit of the pursuit of world-class manufacturing and the need for continuous improvement in terms of cost reduction and improvements in quality, delivery, getting new products to market faster and customer responsiveness. The research focus during the 1990s appears to have shifted towards integration, and the means by which the procurement can work to become recognized as a more significant contributor to the company's success [13]. Over the past few years, there has been an outstanding shift in the way many companies approach buyer-seller relationships. Recent years have seen an increased interest and involvement in buyer-seller partnerships, which tend to be longer term, ongoing, and based on a sharing of the risk of the relationship outcomes [17]. [18] coined the term "lean production" to emphasize both minimal use of input resources for greatly increased output and the fact that the complete system requires coordination of all internal customers and suppliers with their external counterparts. [19] enhanced that idea in his book "Beyond Partnership".

From '90s the literature has exponentially investigated this topic; in particular the long tradition of CP has led to two outcomes. On the one hand, there seems to be a lot of literature mentioning purchasing groups or purchasing consortia. On the other hand, research on cooperative purchasing is still in its infancy [20].

Most sources on CP are found in textbooks and professional publications are often descriptive. Thus, especially compared to vertical buyer-seller cooperation, horizontal buyer-buyer cooperation has not been a major research area until now [21]. Academic research that has been done on $\mathrm{CP}$ has contributed to describing and analyzing several $\mathrm{CP}$ topics under different settings and circumstances. The existing research findings are categorized as follows:

- Advantages and disadvantages of cooperative purchasing [22], [23] and [24];

- Coordination structures of purchasing groups [25] and [26];

- Critical success factors, drivers, and preconditions for cooperative purchasing [27], [28], and [29];

- Development of purchasing groups over time [30], [31] and [32] ;

- Formation of purchasing groups in electronic marketplaces [33] and [34].

The academic sources described above do cover relevant topics. Still, some gaps exist in the CP literature. We found gaps in the research method used, as little large-scale empirical research exists. Moreover literature on $\mathrm{CP}$ within stable enterprise networks is practically inexistence. For this reason, new researches, methodologies, reference framework and application of the developed theories through case studies should be built up. 


\section{The VDO Model}

The Virtual Development Office (VDO) model has been developed within the Italian research project MIGEN $^{1}$, during which the University of Perugia supported the development of an enterprise network from its first steps. The aim of the project was to define a conceptual organizational model for enterprise networks, in order to increase the competitiveness of the SMEs involved. The approach proposed is based on the creation of an independent subject, the VDO, GPT in the case study, which acts as a leading actor, and it has the role of creating, coordinating and managing a community of enterprises [35]. Particularly, it should be the market intelligence of the network, continuously catching business opportunities in the market and positioning the network on it. Moreover, the VDO is the permanent interface to public institutions, financial institutions and research centres. A proactive collaboration with such subjects is a leverage factor in today business. The VDO activities presented above are "external" to the network. However, the VDO also has a crucial role inside the network life. First of all, it has the role of maintaining and consolidating the trust of companies involved in the network by generating and promoting a long-term alliance. By acting as a central player on respect of the "business ecosystem", it promotes both the willing of cooperation, both the readiness to collaborate each time a business opportunity, which for a network can be defined as a "collaboration opportunity" (CO) arises. From a value chain point of view, particularly interesting is the creation of the Virtual Enterprise (VE) or Virtual Organization (VO) for specific business opportunities, since the processes that constitute the value chain, i.e. those activities that represent the value proposition of the network and lead to customer satisfaction will be split amongst the members of the network that are participating in the collaborative opportunity.

\section{The EASM Framework}

This section presents the CP framework, named EASM (Exploring, Analyzing, Selecting, Managing) that has been developed for VDO based networks, and tested in the GPT (Gruppo Poligrafico Tiberino) network case study. A representation of the proposed framework is provided in Figure 1. The VDO has the initial task of Exploring the network, in order to catch potential Collaborative Procurement Opportunities (CPOs) for the partners. During the Exploring phase the VDO explores the most common purchased products by the network companies, and gives a classification of them, with different weights, in terms of costs, volumes, possible buyers, etc. Tools that can support this phase are questionnaires, surveys, interviews, an so on. This action allows the VDO from one side to deeply know the network companies needs, from the other to realize an initial study on the most consumed items or services. The second phase of the CP framework is the "Analyzing" one. During this phase the VDO carefully evaluates the investigated potential CPOs, in order to select those with most potential benefit for the network and possibility of success.

${ }^{1}$ MIGEN (the name comes from the Italian acronym for Innovative Models for Enterprises Network Management) is a research project supported by Italian government with the PRIN (Research Project of National Interest) program. The project involved the Universities of Perugia, Florence and Genoa and it focused on the development of specific models and tools for managing networks of enterprises. 


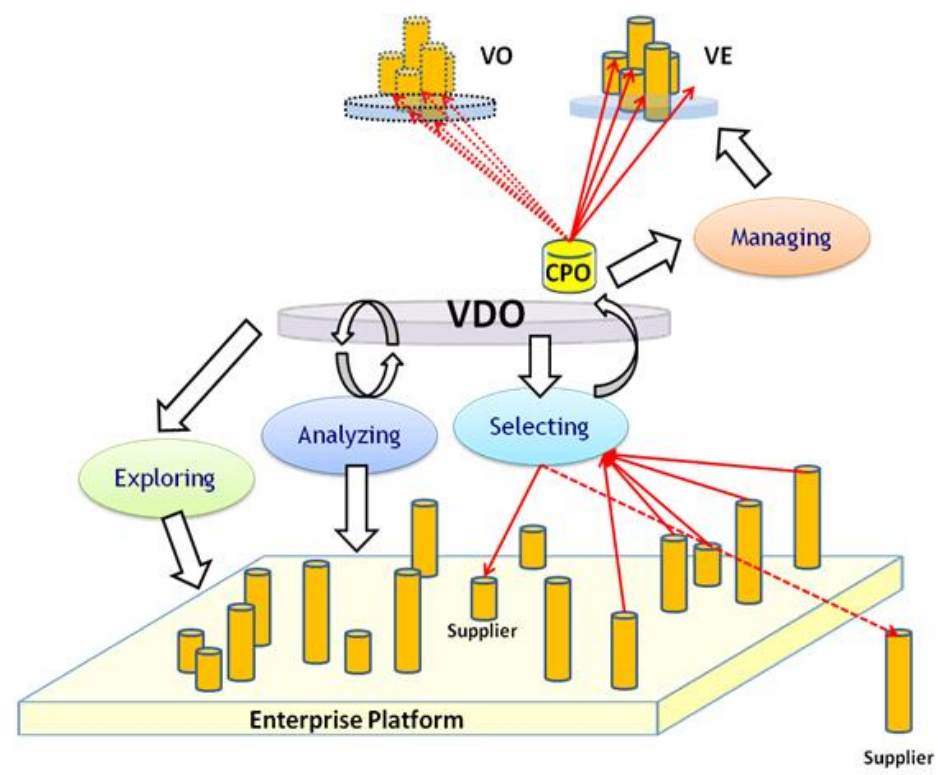

Fig. 1. The EASM Collaborative Procurement Framework for VDO based networks

A validation of the weights correlated to the potential POs is performed by the VDO, in order to avoid incorrect evaluations of these indicators that can lead to financial, economic, structural and competitive losses. Moreover, in this phase the VDO performs an analysis of the potential supplier (that can be internal or external to the network), through supply-chain management and buyer-seller relationship optimization criteria; and it evaluates the cost of the desired products/services, by comparing them with the actual costs of single buyers (companies). Additionally, the VDO individuates the strengths and weaknesses of each potential CPO, and it define a set of indicators that consider economic, financial, trust and reputational indexes. Thus, in this phase the VDO selects only the most highest ranked CPOs and excludes the others with lower evaluation. In the Selecting phase, the VDO selects the companies of the network that can be involved in each of the identified CPOs, as well as the supplier(s) for the CP. In the current phase the VDO realizes the Virtual Enterprise (VE) or the Virtual Organization (VO) (depending if also institutions are involved in the opportunity) for each selected CPO. The VE/VO are the groups of companies selected by the VDO that will benefit of the CPOs advantages. The last phase, the Managing one, is characterized by the management of the VE/VO by the VDO during the projects. In this phase the VDO has the important role of coordinating the $\mathrm{CP}$ processes, maintaining trust among partners, guaranteeing intellectual property rights, optimizing the supply-chain furniture. The VDO can eventually modify the VE/VO actor participation and change the VE/VO structure and parameters, in order to assure increasing benefits for the entire network. The EASM model has been realize by the authors following the Critical Success Factors (CSFs) for implementing a CP approach expressed in the literature during the last decades. In particular a discussion of the model based on the CSFs is proposed in Table 1. The application of the model to the case study is presented in the next paragraph. 
Table 1. CSFs for CP and evaluation of the EASM framework

\begin{tabular}{|c|c|c|}
\hline CSFs & $\begin{array}{l}\text { References } \\
\text { in literature }\end{array}$ & EASM framework managed by the VDO \\
\hline $\begin{array}{l}\text { 1) Commitment and } \\
\text { internal support }\end{array}$ & $\begin{array}{l}{[36],[30]} \\
{[27],[37]} \\
{[38] \text { and }[39]}\end{array}$ & $\begin{array}{l}\text { 1. All member contributes are comparable in terms of resources } \\
\text { and efforts; } 2 \text {. All members have internal support; } 3 \text {. All } \\
\text { members rarely change representatives; } 4 \text {. The VDO acts as a } \\
\text { leader; } 5 \text {. In total, sufficient efforts and activities are contributed } \\
\text { to be able to run the group successfully; }\end{array}$ \\
\hline 2) Communication & $\begin{array}{l}{[40],[41],} \\
{[42]} \\
\text { and }[39] \\
\end{array}$ & $\begin{array}{l}\text { 6. VDO communicates and keeps each other up-to-date } \\
\text { regarding current projects; } 7 \text {. VDO communicates and keeps } \\
\text { each other up-to-date regarding new potential projects; }\end{array}$ \\
\hline $\begin{array}{l}\text { 3) Allocation of gains } \\
\text { and costs }\end{array}$ & {$[43]$} & 8. Fair allocation of gains and costs; \\
\hline $\begin{array}{l}\text { 4) Formality of the } \\
\text { group }\end{array}$ & $\begin{array}{l}{[6],[44],} \\
{[45],[30],} \\
{[37],[31]} \\
\text { and }[39] \\
\end{array}$ & $\begin{array}{l}\text { 9. VDO is a formal structured stable network; } 10 . \text { VDO make } \\
\text { engagements regarding important decision moments; } 11 . \text { VDO } \\
\text { reports important performances of the group periodically; }\end{array}$ \\
\hline $\begin{array}{l}\text { 5) Interorganizational } \\
\text { trust }\end{array}$ & $\begin{array}{l}{[46],[36]} \\
{[47],[48]} \\
{[37] \text { and }[49]}\end{array}$ & $\begin{array}{l}\text { 12. All members are honest and loyal due to the affiliation at the } \\
\text { VDO network; } 13 \text {. All members like each other personally; } 14 \text {. All } \\
\text { members meet one's commitments; }\end{array}$ \\
\hline $\begin{array}{l}\text { 6) Knowledge on how } \\
\text { to cooperate }\end{array}$ & [37] and [31] & 15. All members contribute unique knowledge; \\
\hline 7) Organization & {$[25]$} & $\begin{array}{l}\text { 16. All members have a similar influence on the group activities } \\
\text { and decisions; } 17 \text {. Voluntary participation; }\end{array}$ \\
\hline $\begin{array}{l}\text { 8) Uniformity of the } \\
\text { members }\end{array}$ & $\begin{array}{l}{[50],[41]} \\
\text { and }[51]\end{array}$ & $\begin{array}{l}\text { 18. All members have similar objectives to participate in the } \\
\text { group; 19. All members have similar organizational cultures; } \\
\text { 20. All members have similar procedures. }\end{array}$ \\
\hline
\end{tabular}

\section{The Case Study}

The EASM CP framework has been tested in an Italian network of 20 companies belonging to the printing and packaging sector, namely the Gruppo Poligrafico Tiberino (GPT). Through the Exploring phase authors investigated the most common products/services purchased in the network. Since the manufacturing nature of the partners, several products/services belonging to the manufacturing sector have been individuated through the use of a questionnaire, such as for example pallets, cardboard, paper, transports, software applications, services, etc..

The Exploring and Analyzing phase, where classifications and multi-criteria evaluation were performed as suggested in paragraph 5, resulted in the identification of 3 potential CPOs: pallets, cardboard and paper. These choices are justified since the purchasing of these products within the network covered very high volumes, as shown in Table 2. During the Analyzing phase the best suppliers were identified and the VEs/VOs could have been built up in the Selecting phase. Table 2 summarizes the three CPOs actually performed in GPT, by highlighting the total volumes in terms of number of products and monetary value, the average cost of purchasing and the average saving in terms of money percentage. 
Table 2. CPOs information

\begin{tabular}{|c|c|c|c|c|c|}
\hline \multirow[b]{2}{*}{ CPOs } & \multicolumn{2}{|c|}{ Volumes } & \multirow[b]{2}{*}{$\begin{array}{c}\text { Average } \\
\text { price/product }\end{array}$} & \multicolumn{2}{|c|}{ Average money saving } \\
\hline & $\begin{array}{c}\text { No. Prod. Per } \\
\text { year }\end{array}$ & Total amount & & Percentage & $\begin{array}{c}\text { Total amount } \\
\text { per year }\end{array}$ \\
\hline Pallet & $90.550 \mathrm{pz}$ & $602 \mathrm{~K} € /$ year & $6,64 €$ & $22,78 \%$ & $137 \mathrm{~K} €$ \\
\hline Cardboard boxes & $2.641 .500 \mathrm{pz}$ & 1,4 M€/year & $0,53 € / p$ & $11,80 \%$ & $165,2 \mathrm{~K} €$ \\
\hline Paper & 3000 tons & $3 \mathrm{M} € /$ year & $1000 € /$ ton & $5,67 \%$ & $170,1 \mathrm{~K} €$ \\
\hline
\end{tabular}

As shown in Table 2, an average cost reduction has been realized through a CP action in GPT: $472,3 \mathrm{~K} €$ is the total amount saved in 2008 by GPT. This money saving is due to an increasing contractual power of the companies with the suppliers.

Companies that were before buying raw materials from different sellers, can now benefit of best prices, since the very high requested volumes. Table 2 shows high values of average money saving percentage for each CPO; this is an important result, since the identified CPOs involve low value-added products. Thus, direct costs have significantly been reduced by the application of the EASM framework, achieving the most important Collaborative Procurement objective.

\section{Conclusions}

This paper has investigated the leading topic of Collaborative Procurement within enterprise networks. After the definition of what "collaborative procurement" is, the literature available has been critically reviewed so as to highlight consolidate knowledge and lacks. Based on the learning from the literature, the authors presented a CP framework, EASM, that has been developed for an innovative typology of business networks, namely the Virtual Development Office (VDO) networks. The model proposed offers a step by step methodology for implementing CP initiatives within networks, and extend its applicability more generally to all networks having a central hub.

Future research will focus on multiple field test of the model, so as to identify criticalities of application and optimizing therefore the methodology based on feedbacks. Moreover, the applicability to other typology of business networks should be evaluated.

\section{References}

1. Camarinha-Matos, L.M., Afsarmanesh, H.: Elements of a base VE infrastructure. Journal of Computers in Industry 51(2), 139-163 (2003)

2. MacCarthy, T., Golicic, S.: Implementing collaborative forecasting to improve supply chain performances. International Journal of Physical Distribution \& Logistic Management 32(6), 431-454 (2002)

3. McLaren, T., Head, M.: Supply Chain collaboration alternatives: understanding the expected costs and benefits. Internet Research: Electronic Networking Applications and Policy 2(4), 348-364 (2000) 
4. Horvath, L.: Collaboration: the key to value creation in supply chain management. Supply Chain Management: An International Journal 6(5), 205-217 (2001)

5. Schotanus, F., Telgen, J.: Developing a typology of organisational forms of cooperative purchasing. Journal of Purchasing \& Supply Management 13, 53-68 (2007)

6. Bakker, E., Walker, H., Harland, C.: Organizing for collaborative procurement: An initial conceptual framework. In: Thai, K., Piga, G. (eds.) Advancing public procurement: Practices, innovation and knowledge-sharing, pp. 14-44. PrAcademics Press, Boca Raton (2006)

7. Hendrick, T.E.: Purchasing consortiums: Horizontal alliances among firms buying common goods and services: What? Who? Why? How? Tempe: Center for Advanced Purchasing Studies (1997)

8. Rozemeijer, F.: Creating corporate advantage in purchasing. Ph.D. dissertation, Eindhoven (the Netherlands): Technical University of Eindhoven (2000)

9. Tella, E., Virolainen, V.M.: Motives behind purchasing consortia. International Journal of Production Economics, 93-94, 161-168 (2005)

10. Ammer, D.S.: Is your purchasing department a good buy? Harvard Business Review, 136159 (1974)

11. Farmer, S.H.: The impact of supply markets on corporate planning. Long Range Planning, 10-16 (1972)

12. Kisser, G.E.: Elements of purchasing strategy. Journal of Purchasing and Materials Management, 3-7 (1976)

13. Ellram, L.M., Carr, A.S.: Strategic purchasing: a history and review of the literature. International Journal of Purchasing and Materials Management 11 (1994)

14. Browning, J.M., Zahriskie, N.B., Huellmantel, A.B.: Strategic purchasing planning. Journal of Purchasing and Materials Management 19, 24 (1983)

15. Spekman, R.E.: Competitive procurement strategies. Building strength and reducing vulnerability. Long Range Planning 18(1), 94-99 (1985)

16. Morgan, J.P.: Are you aggressive enough for the 1990s. Purchasing, 50-57 (1989)

17. Ellram, L.M.: Partnering pitfalls and success factors. International Journal of Purchasing and Materials Management 36 (1995)

18. Womack, J., Jones, D., Rooa, D.: The Machine that Changed the World. Macmillan Publishing Company, New York (1990)

19. Lamming, R.C.: Beyond Partnership: Strategies for Innovation and Lean Supply. PrenticeHall, Englewood cliffs (1993)

20. Essig, M.: Purchasing consortia as symbiotic relationships. European Journal of Purchasing and Supply Management 6(1), 13-22 (2000)

21. Ellram, L.M.: A managerial guideline for the development and implementation of purchasing partnerships. International Journal of Purchasing and Materials Management 27(3), 28 (1991)

22. Ball, D., Pye, J.: Library purchasing consortia: The UK periodicals supply market. Learned Publishing 13(1), 25-35 (2000)

23. Evans, R.G.: Public health insurance: The collective purchase of individual care. Health Policy 7(2), 115-134 (1987)

24. Nollet, J., Beaulieu, M.: Should an organization join a purchasing group? Supply Chain Management 10(1), 11-17 (2005)

25. Enthoven, A.C.: On the ideal market structure for third-party purchasing of health care. Social Science and Medicine 39(10), 1413-1424 (1994)

26. Galaskiewicz, J.: Interorganizational relations. Annual Review of Sociology 11, 281-304 (1985) 
27. Doucette, W.R.: Influences on member commitment to group purchasing organizations. Journal of Business Research 40(3), 183-189 (1997)

28. Exworthy, M., Peckham, S.: The contribution of coterminosity to joint purchasing in health and social care. Health and Place 4(3), 233-243 (1998)

29. Huber, B., Sweeney, E., Smyth, A.: Purchasing consortia and electronic markets: A procurement direction in integrated supply chain management. Electronic Markets 14(4), 284294 (2004)

30. D'Aunno, T.A., Zuckerman, H.S.: A life-cycle model of organizational federations: the case of hospitals. Acadamy of Management Review 12(3), 534-545 (1987)

31. Johnson, P.F.: The pattern of evolution in public sector purchasing consortia. International Journal of Logistics: Research and Applications 2(1), 57-73 (1999)

32. Nollet, J., Beaulieu, M.: The development of group purchasing: an empirical study in the healthcare sector. Journal of Purchasing and Supply Management 9(1), 3-10 (2003)

33. Granot, D., Sošić, G.: Formation of alliances in internet-based supply exchanges. Management Science 51(1), 92-105 (2005)

34. Yuan, S.T., Lin, Y.H.: Credit based group negotiation for aggregate sell/buy in e-markets. Electronic Commerce Research and Applications 3(1), 74-94 (2004)

35. Botarelli, M., Taticchi, P., Cagnazzo, L.: The Virtual Development Office framework for business Networks: a case study from the Umbrian packaging district. In: Pervasive Collaborative Networks. IFIP International Federation for Information Processing, vol. 283, pp. 611-618 (2008)

36. Bakker, E., Walker, H., Harland, C., Warrington, J.: The effect of collaborative purchasing structures on managing cooperation. In: IPSERA conference proceedings, San Diego, United States (2006)

37. Hoffmann, W., Schlosser, R.: Success factors of strategic alliances in small and mediumsized enterprises, an empirical study. Longe Range Planning 34(3), 357-381 (2001)

38. Kanter, R.M.: Collaborative advantage. Harvard Business Review 72(4), 96-108 (1994)

39. Niederkofler, M.: The evolution of strategic alliances: Opportunities for managerial influence. Journal of Business Venturing 6(4), 237-257 (1991)

40. Anderson, J.C., Narus, J.A.: A model of distributor firm and manufacturer firmworking partnerships. Journal of Marketing 54(1), 42-58 (1990)

41. Laing, A., Cotton, S.: Patterns of inter-organizational purchasing: Evolution of consortiabased purchasing amongst GP fundholders. European Journal of Purchasing and Supply Management 3(2), 83-91 (1997)

42. Mohr, J., Spekman, R.: Characteristics of partnership success: Partnership attributes, communication behavior, and conflict resolution techniques. Strategic Management Journal 15(2), 135-152 (1994)

43. Heijboer, G.: Mathematical and statistical analysis of initial purchasing decisions. Ph.D. dissertation, Enschede (the Netherlands): University of Twente (2003)

44. Corsten, D., Zagler, M.: Purchasing consortia and internet technology. In: IPSERA conference proceedings, Belfast and Dublin, pp. 975-986 (1999)

45. Das, T.K., Teng, B.S.: Alliance constellations: A social exchange perspective. The Academy of Management Review 27(3), 445-456 (2002)

46. Aulakh, P.S., Kotabe, M., Sahay, A.: Trust and performance in cross border marketing partnerships: A behavioral approach. Journal of International Business Studies 27(5), 1005-1032 (1996)

47. Browning, L.D., Beyer, J.M., Shetler, J.C.: Building cooperation in a competitive industry: SEMATECH and the semiconductor industry. Academy of Management Journal 38(1), 113-151 (1995) 
48. Das, T.K., Teng, B.S.: Trust, control, and risk in strategic alliances: An integrated framework. Organization Studies 22(2), 251-283 (2001)

49. Gulati, R.: Does familiarity breed trust? The implications of repeated ties for contractual choice in alliances. Academy of Management Journal 38(1), 85-112 (1995)

50. Woolthuis, K.R.: Sleeping with the enemy: trust, dependence and contract in interorganizational relationships. Ph.D. dissertation, Enschede (the Netherlands): University of Twente (1999)

51. Polychronakis, Y., Syntetos, A.: 'Soft' supplier management related issues: An empirical investigation. International Journal of Production Economics 106, 431-449 (2007) 